\title{
Highlights of the USGS Cooperative Water Program in Massachusetts
}

The U.S. Geological Survey (USGS) is the Nation's primary natural-resources science agency, engaged in data collection and interpretive studies in all 50 States. Cooperation between the USGS and the Commonwealth of Massachusetts began in 1884 with surveying for the first set of USGS topographic maps in the Commonwealth. The Cooperative Water Program in Massachusetts began in 1904, with the establishment of a streamflow gage on the Connecticut River at Montague City. Building upon these early efforts, the USGS and the Commonwealth now pursue a highly diverse Cooperative Water Program. This Fact Sheet highlights several important aspects of this program.

\section{Long-Term Monitoring of Massachusetts Water Resources}

The USGS stream-gaging network in Massachusetts now includes 89 stations, with 73 of these stations reporting real-time flow and water-level data on the Web (http://ma.water.usgs.gov/water/). A wide variety of users, including recreational enthusiasts, watershed associations, engineering consultants, university scientists, and water managers from local, State, and Federal agencies depend upon these data.

The USGS ground-water observation-well network consists of 92 wells distributed throughout Massachusetts in a variety of geologic settings. Water-level information from this network meets the needs of many types of users.

One important application is the prediction of maximum ground-water levels for the siting of Title 5 septic systems. Another application is the use of ground-water levels to predict summer low flows in streams. At present, nine of these wells record water levels continuously, with real-time reporting to the Web (http://ma.water.usgs.gov/water/).

\section{Urban Studies-Providing Vital Information for Water-Resources Restoration}

The restoration of urban centers is a key aspect of the "smart growth" vision. The USGS circulation model of Boston Harbor and Massachusetts Bay, prepared in cooperation with the Massachusetts Water Resources Authority, has facilitated the successful cleanup of Boston Harbor. The USGS has also worked in the Mystic, Muddy, Lower Charles, Neponset, and North Coastal River Basins to characterize bottom-sediment contaminants, stormwater flows and quality, and the potential water-quality benefits of stormwater best management practices. Through these studies, the USGS is helping to establish the scientific framework for urban environmental restoration in Massachusetts.

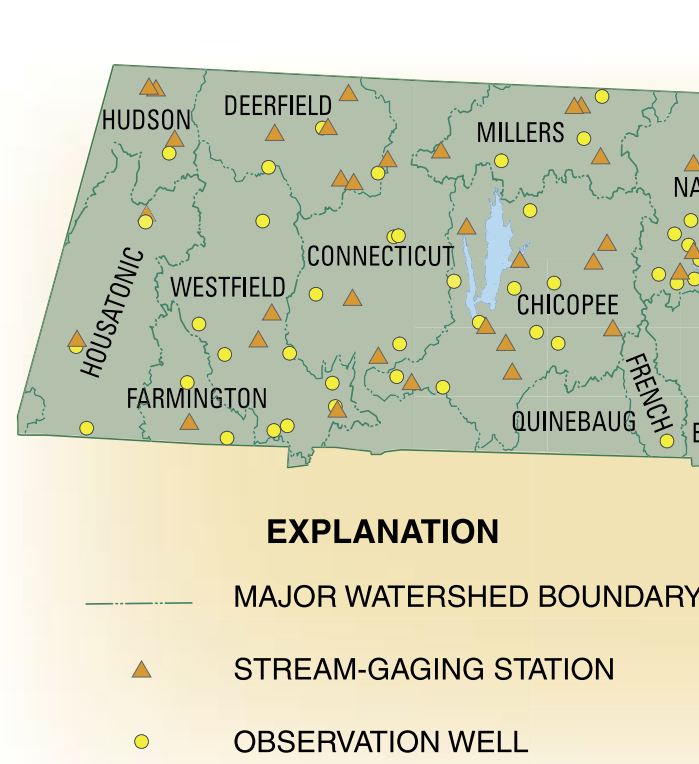

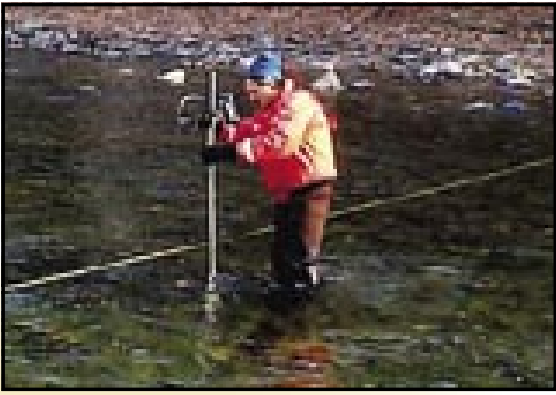

Streamflow measurement, Green River near Colrain, Massachusetts
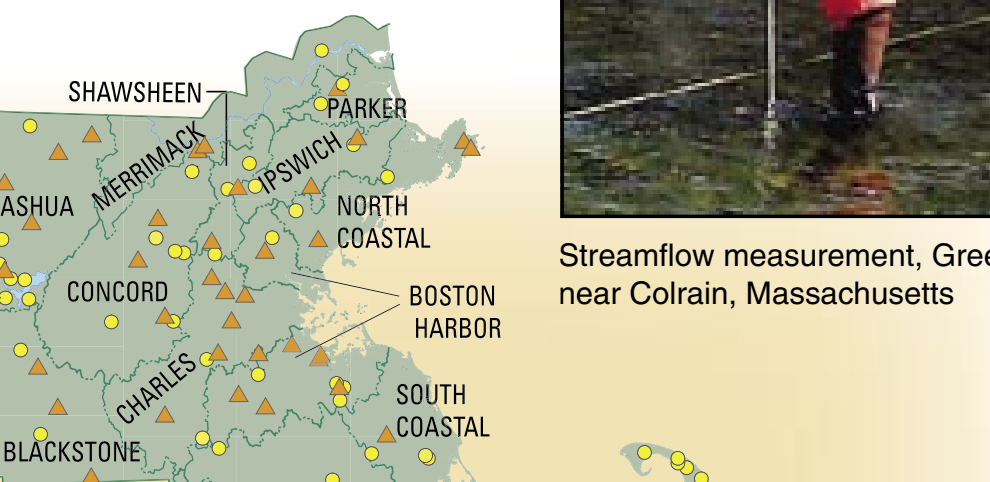

U.S. Geological Survey stream-gaging stations and observation wells in Massachusetts 


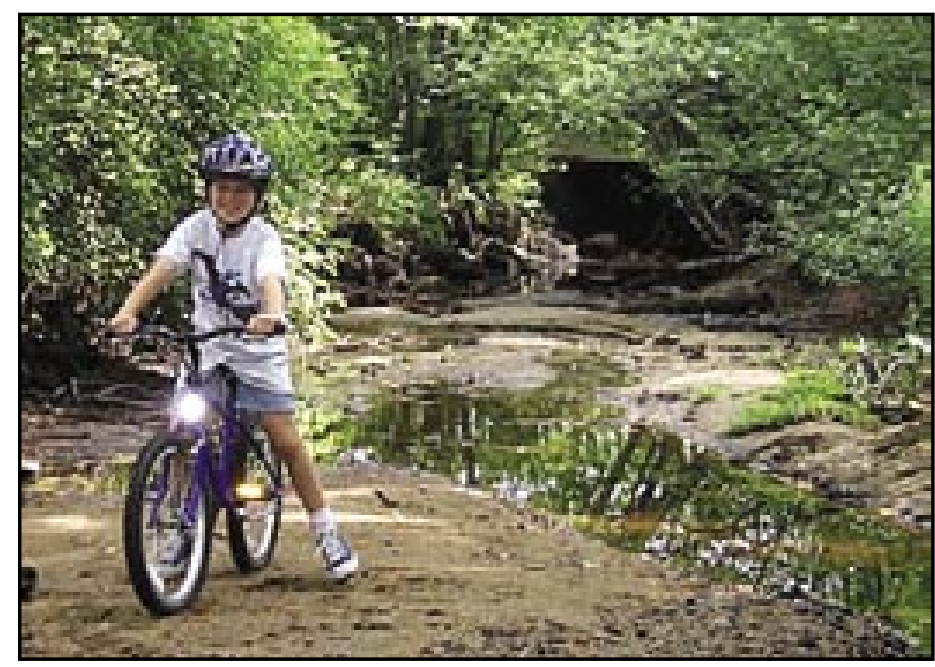

Depleted streamflow in the Ipswich River near Reading, Massachusetts

\section{Basin Modeling-Assessing the Effects of Urban Sprawl, Stressed Basins, and Aquatic Habitat}

USGS scientists have recently completed water-resources modeling studies for rapidly developing eastern Massachusetts watersheds (basins) now experiencing urban sprawl, including the Ipswich, Upper Charles, and Assabet River Basins.

Cooperatively funded by the USGS and the Commonwealth, and constructed in consultation with basin stakeholders, these models are now being used to test the effects of alternative land-use, water-withdrawal, and wastewater-discharge scenarios on water availability for human and ecological needs. In tandem with the modeling projects, the USGS and cooperating State agencies are also assessing the fish communities of these river systems and their instream-flow and habitat requirements.

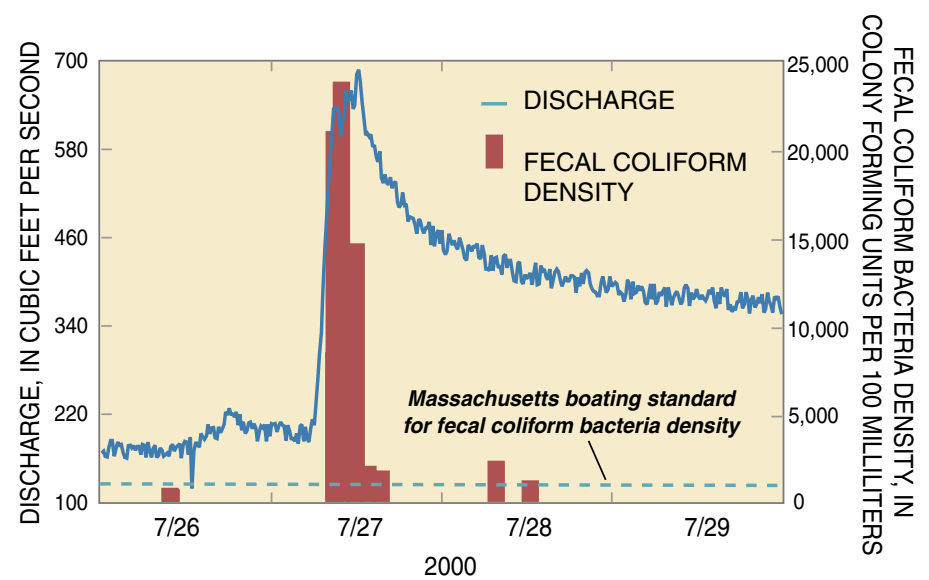

Effects of a summer rainstorm on streamflow and bacteria density in the Charles River near Watertown Dam, July 27, 2000. Note that streamflow remains elevated for several days after the July 27 storm due to the slow release of stored water from upstream wetlands and impoundments.

\section{Aquifer Studies-Helping to Protect Drinking Water Supplies}

Nearly half of Massachusetts drinking water comes from ground-water sources. In areas such as Cape Cod and the Plymouth-Carver region, virtually all public supplies are drawn from sole-source aquifers. The USGS, in cooperation with the Commonwealth, has conducted many ground-water assessments and modeling studies to enhance the protection, management, and restoration of Massachusetts ground-water resources. On Cape Cod, aquifer-cleanup activities at the Massachusetts Military Reservation have relied to a large extent upon USGS models of the underlying ground-water flow system. Most recently, the USGS is using new or existing models to delineate contributing areas to public-supply wells, ponds, and coastal embayments on Cape Cod, to determine optimal approaches to wastewater management, and to describe and help prevent the process of salt-water intrusion in coastal areas.

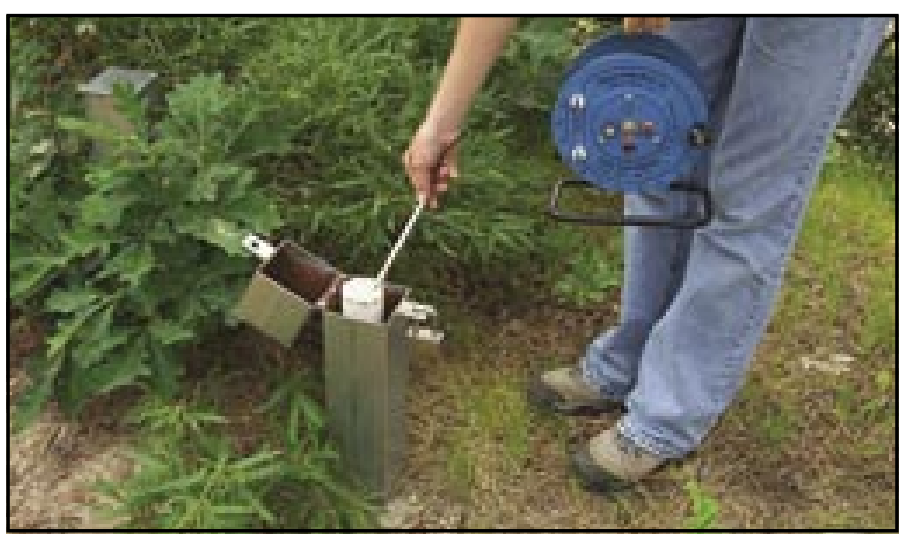

Ground-water-level monitoring, Cape Cod

\section{Leading-Edge Science for Public Health and Environmental Protection}

In collaboration with Massachusetts agencies, the USGS Cooperative Water Program has pioneered the application of innovative approaches to water-resources studies in the Commonwealth, including:

- PCB fingerprinting to pinpoint locations of contaminants entering rivers,

- microbial source-tracking using DNA-based identification techniques,

- state-of-the-art computer modeling of watersheds, aquifers, and ground-water/surface-water interaction, and

- optimization modeling of water-resource-management alternatives.

By Peter K. Weiskel

For more information, contact:

Wayne Sonntag, District Chief

U.S. Geological Survey MassachusettsRhode Island District
10 Bearfoot Road

Northborough, MA 01532

508-490-5000

508-490-5068 (fax)

dc_ma@usgs.gov

(http://ma.water.usgs.gov) 